\title{
Efektivitas bahan ajar cerita bergambar bemuatan religius \\ terhadap prestasi belajar siswa kelas 1 sekolah dasar
}

\author{
${ }^{1}$ Yunita Sari, ${ }^{2}$ Sari Yustiana \\ 1yunitasari@unissula.ac.id \\ 1,2Pendidikan Guru Sekolah Dasar, Fakultas Keguruan dan Ilmu Pendidikan, \\ Universitas Islam Sultan Agung
}

\begin{abstract}
ABSTRAK
Penelitian ini bertujuan untuk mengetahui efektivitas bahan ajar cerita bergambar bermuatan religius terhadap prestasi belajar. Subjek penelitian ini siswa kelas 1 SDN Beji 03 yang berjumlah 30 siswa. Bahan ajar yang digunakan adalah buku bergambar bermuatan nilai religius. Penelitian ini menggunakan metode penelitian eksperimental dengan desain penelitian yang digunakan adalah pre-eksperiment one group pre-test-postest. Soal tes berbentuk pilihan ganda dengan jumlah 20 soal. Analisis data menggunakan Uji Gain Ternomalisasi. Hasil penelitian menunjukkan jumlah nilai pretes dari seluruh siswa adalah 1890 dan jumlah nilai postes dari seluruh siswa adalah 2480. Hasil tersebut diolah menggunakan rumus $\mathrm{N}$-Gain dan mencapai nilai 0,53 dengan interpretasi "Sedang", dengan hasil ini maka terdapat peningkatan yang signifikan terhadap prestasi belajar siswa dengan menggunakan bahan ajar cerita bergambar bermuatan nilai religius. Dapat disimpulkan bahwa bahan ajar bermuatan nilai religius efektif terhadap prestasi belajar siswa kelas 1 sekolah dasar.
\end{abstract}

Kata kunci: bahan ajar, religius, prestasi belajar

\section{The effectiveness of religious-based pictorial story teaching materials on the learning achievement of $1^{\text {st-grade students of elementary school }}$}

\begin{abstract}
This study aimed to determine the effectiveness of religiously charged picture story teaching materials on student achievement. The subjects of this study were students of grade 1 SD Negeri Beji 03, totaling 30 students. The teaching materials used were picture books with religious values. This study uses experimental research methods with the research design used is preexperiment one group pre-test-postest. The test questions were multiple choices with a total of 20 questions. Data analysis using Normalized Gain Test. The results showed that the total pretest score of all students was 1890 and the total posttest score of all students was 2480. The results were processed using the N-Gain formula and reached a value of 0.53 with the interpretation of "Medium", with this result there was a significant increase in student achievement by using picture story teaching materials containing religious values. It can be concluded that teaching materials containing religious values are effective on the learning achievement of grade 1 elementary school students.
\end{abstract}

Keywords: teaching materials, religious-based pictorial story, learning achievement

Received: June 21st,2021 Reviewed: June 24th, 2021 Accepted:July 28th, $2021 \quad$ Published: July 31st, 2021 


\section{PENDAHULUAN}

Pendidikan merupakan sesuatu hal yang paling utama yang menjadi adanya tolak ukur perkembangan suatu bangsa agar tidak tertinggal dari bangsa lain. Sehingga, Sekolah Dasar merupakan sebuah tempat dalam mendapatkan sebuah pengalaman pertama yang dimana bisa memberikan dasar-dasar untuk pembentuk dari adanya kepribadian individu (Setyarini, 2019).

Karakter merupakan hal terpenting yang harus ditumbuh kembangkan dengan baik dan benar dalam diri setiap generasi muda. Karakter adalah sebuah dasar dan fondasi utama untuk dapat membentengi diri dari segala hal buruk yang hadir dalam dinamika kehidupan. Pembelajaran bertujuan untuk memberikan pengetahuan dan nilai-nilai penting kepada peserta didik. Nilai-nilai penting itu tidak dapat diperoleh jika guru tidak menggunakan sumber pembelajaran yang menarik dalam kegiatan belajar mengajar. Dalam mencapai tujuan yang telah ditentukan, dibutuhkan beberapa bahan yang sangat mendukung untuk diberikan kepada peserta didik, beberapa bahan yang dapat mendukung untuk mencapai tujuan yang telah ditentukan berupa bahan ajar yang harus dismapaikan pendidik kepada peserta didik. Dalam memberikan bahan ajar tidak dapat dilakukan secara sembarangan, bahan ajar tersebut harus dapat dipertanggung jawabkan serta memiliki pengetahuan yang bersifat ilmiah atau memenuhi ketentuan untuk mencapai tujuan.

Bahan ajar yang digunakan oleh pendidik untuk mempermudah dalam menyampaikan materi pembelajaran bagi peserta didik serta peserta didik lebih mudah untuk menerima materi yang diberikan dengan bantuan bahan ajar. Sistem Pendidikan Nasional yang telah diatur dalam UU No. 20 Tahun 2003 kemudian dijabarkan dalam PP No. 19 Tahun 2015 terkait dengan Standar Nasional Pendidikan pasal 19 ayat 1 bahwa di dalamnya, telah tertera bahwa proses pembelajaran yang ada di sekolah dapat dilakukan dengan cara yang interaktif, pembelajaran yang memberi inspirasi, pembelajaran yang membahagiakan, serta pembelajaran yang memberi tantangan, agar dapat menumbuhkan keaktifan, menumbuhkan kreativitas, menumbuhkan rasa mandiri, sesuai dengan bakat, minat serta perkembangan jasmani, rohani yang dimiliki pada setiap diri peserta didik. Sehingga ketika guru merancang kegiatan belajar mengajar setidaknya dilakukan dengan menggunakan media serta sumber belajar agar dapat mempermudah pendidik dan peserta didik dalam menyampaikan dan menerima tujuan pembelajaran yang diinginkan. Menurut Ahmadi dan Supriyono (Aslach, 2020), 
dalam proses belajar mengajar, guru mempunyai tugas untuk mendorong, membimbing dan memberikan fasilitas belajar bagi siswa untuk mencapai tujuan. Guru mempunyai tanggung jawab untuk melihat segala sesuatu yang terjadi dalam kelas untuk membantu proses perkembangan siswa. Penyampaian materi pelajaran hanyalah merupakan salah satu dari berbagai kegiatan dalam belajar sebagai suatu proses yang dinamis dalam segala fase dan proses perkembangan anak.

Proses belajar mengajar yang berlangsung harus dilaksanakan dan sesuai dengan perubahan zaman yang terus berkembang. Bahan ajar disusun secara sistematis artinya bahan ajar tersebut disusun secara urut sehingga memudahkan peserta didik belajar. Dengan begitu bahan ajar memungkinkan peserta didik dapat mempelajari suatu kompetensi atau keterampilan yang harus dikuasai oleh peserta didik secara utuh dan terpadu sehingga peserta didik dapat mencapai tujuan pembelajaran yang di harapkan. Ada banyak dan bermacam-macam bentuk bahan ajar yang dapat ditemui. Bahan ajar berbentuk audio, audio-visual, cetak, multimedia, dan visual. Bermacam-macamnya bahan ajar menyesuaikan dengan materi yang ingin disampaikan. Contoh dari bahan ajar cetak diantaranya adalah LKS, modul, buku. Bahan ajar adalah seperangkat materi yang disusun secara sistematis, baik tertulis maupun tidak tertulis, sehingga tercipta lingkungan atau susasana yang memungkinkan peserta didik untuk belajar (I. Lestari, 2018).

Adapun kaidah-kaidah yang harus dipenuhi dalam menyusun bahan ajar, yaitu self-instructional yang artinya meminimalkan keinginan peserta didik untuk bergantung kepada orang lain agar peserta didik terbiasa untuk belajar percaya diri; self-contained artinya semua materi yang dipelajari menyatu dalam satu set baik itu kompetensi yang diharapkan atau subkompetensi bagian-bagian kecil lain; standalone artinya dalam pengunaannya, bahan ajar bisa digunakan tanpa harus terkait kepada bahan ajar yang lain, adaptive artinya bahan ajar dapat dengan mudah menyesuaikan terhadap perkembangan ilmu dan tehnologi; serta friendly artinya perintah dari penjelasan informasi yang disampaikan bersifat menolong (M. A. Lestari et al., 2017).

Masalah yang sering dihadapi pada anak sekolah dasar adalah penggunaan sumber belajar yang kurang menarik bagi peserta didik dan dalam pembelajaran tidak selalu menggunakan sumber belajar. Sumber belajar yang ada sifatnya yang terbatas membuat siswa malas belajar hal ini dapat berdampat terhadap prestasi belajar siswa. Bahan ajar merupakan salah satu dari sumber belajar. Penggunaan bahan ajar yang kurang menarik dan terbatas membuat siswa malas membaca. 
Peserta didik hendaknya mulai diajak untuk aktif dalam mengikuti pembelajaran membaca agar minat membacanya dapat tumbuh dan berkembang dengan baik. Minat membaca peserta didik dapat ditumbuhkembangkan melalui adanya banyak bacaan yang menarik bagi peserta didik. Salah satu untuk mewujudkan pembelajaran yang menarik perhatian peserta didik ialah sumber belajar yang dikemas dalam bentuk buku bergambar. "Buku cerita bergambar mempunyai teks singkat, umumnya terdiri dari 32 halaman yang terdiri dari kata-kata dan gambar yang digabungkan dalam cerita untuk menyampaikan informasi" (Ratnasari \& Zubaidah, 2019). Peranan gambar sangat penting bagi anak-anak dalam proses belajar. Pada umumnya anak lebih tertarik membaca buku yang mempunyai banyak gambar. Karena dirangkai sedemikian rupa sehingga lebih memikat perhatian anak, para orang tua maupun guru akan lebih mudah dalam menyampaikan materi dengan baik menggunakan cerita bergambar yang disukai oleh peserta didik (M. A. Lestari et al., 2017).

Sebuah buku cerita bukan hanya berupa buku yang menyatukan antara tulisan dengan penyajian dihiasi gambar. Tentunya buku cerita memiliki beberapa persyaratan agar buku tersebut dikatakan layak untuk di gunakan terutama anak-anak. Sebuah buku cerita bukan hanya berupa buku yang menyatukan antara tulisan dengan penyajian dihiasi gambar. Tentunya buku cerita memiliki beberapa persyaratan agar buku tersebut dikatakan layak untuk digunakan terutama anak-anak sebagai medium untuk membaca karena buku cerita yang baik memiliki ketentuan, di antaranya: a) tampilan visual buku didesain dengan menggunakan tambilan full color; b) tampilan visual buku cerita lebih menonjolkan gambar dibandingkan dengan tulisannya; c) ragam huruf dalam buku cerita mempunyai tingkat keterbacaan yang efektif bagi anakanak; d) judul buku cerita telah mewakili keseluruhan isi cerita; e) tampilan warna mampu memberikan persepsi dan mudah ditangkap oleh alat penglihatan (Effendy et al., 2013).

Berdasarkan hasil observasi dan hasil wawancara dengan Ibu Lutfi Haryati (guru kelas 1) SDN Beji 03 pada bulan Maret 2020. Ditemukan berbagai kendala diantaranya keterbatasan guru dalam mengembangkan bahan ajar yang menarik untuk siswa. Bahan ajar yang tersedia di sekolah belum memenuhi kebutuhan siswa. Keterbatasan bahan ajar membuat siswa malas untuk belajar hal ini dapat menyebabkan minat membaca rendah serta prestasi belajar rendah. Nilai kelas 1 yang mencapai KKM (Kriteria Ketuntasan Minimum) kurang dari separuh dari 
jumlah siswa di kelas 1 dan prestasi belajar siswa belum maksimal. Nilai-nilai religus dalam bahan ajar yang tersedia disekolah belum sepenuhya ada. Hanya pada tema-tema tertentu saja. Salah satu yang dapat dilakukan guru agar pembelajaran lebih menarik ialah guru dapat mengembangkan bahan ajar yang sudah ada menjadi lebih menarik agar peserta didik tidak mudah bosan ketika mengikuti pembelajaran di kelas.

Pembelajaran adalah kegiatan guru secara terprogram dalam desain instruksional untuk membuat peserta didik belajar aktif, yang menekankan pada penyediaan sumber belajar (Asfihani, 2019). Salah satu untuk mewujudkan pembelajaran yang menarik perhatian peserta didik ialah bahan ajar yang dikemas dalam bentuk buku bergambar dengan menanamkan nilai-nilai religius. Buku cerita bergambar mampu menarik perhatian karena tampilannya sangat digemari oleh kalangan anak-anak. Buku cerita bergambar memiliki fungsi yang dapat dugunakan sebagai penghias dan pendukung dalam cerita yang dapat membantu memudahkan proses pemahaman terhadap isi buku tersebut. Buku cerita bergambar merupakan suatu kesatuan cerita yang disertai dengan gambar-gambar. Melalui buku cerita bergambar, diharapkan pembaca dapat dengan mudah menerima informasi dan deskripsi cerita yang akan disampaikan. Sehingga, buku cerita bergambar dapat tergolong layak untuk digunakan sebagai media dalam proses belajar-mengajar bagi siswa kelas rendah (Fitriani et al., 2019).

Buku bergambar merupakan bahan ajar pendamping digunakan untuk memperluas serta mengembangkan materi agar peserta didik mendapat pengetahuan yang luas serta pengetahuan yang lebih banyak. Cara agar peserta didik dapat memperluas dan mendapat pengetahuan yang lebih banyak dapat dimulai dengan membaca, melaui kegiatan membaca peserta didik dapat memperluas dan mendapat pengetahuan yang lebih banyak. Kegiatan ini sejalan dengan apa yang telah dicantumkan dalam UU No. 20 Tahun 2003 Pasal 4 ayat 5, pendidikan dapat diadakan melalui budaya membaca, menulis, serta berhitung untuk seluruh rakyat. Untuk mewujudkan hal tersebut peserta didik tidak hanya membaca buku siswa dan bahan ajar, namun peserta didik dapat menyeimbangkan dengan membaca buku bahan ajar pendamping, untuk memperluas dan memperkaya pengetahuan, sehingga siswa lebih fokus dan senang mengikuti pembelajaran.

Buku cerita bergambar ini juga dapat dijadikan bahan bacaan untuk semua peserta didik baik dari kelas rendah maupun tinggi. Peserta didik bukan hanya 
sekedar melihat gambar namun juga mengetahui informasi didalamnya secara singkat. Ketika pembelajaran guru dapat menjadikan gambar dalam buku sebagai materi permainan untuk siswa, sehingga pembelajaran lebih menarik dan menyenangkan. Tujuan penelitian ini adalah untuk mengetahui keefektivan bahan ajar cerita bergambar bermuatan nilai religius terhadap prestasi belajar siswa kelas 1 sekolah dasar.

\title{
METODE PENELITIAN
}

Penelitian ini merupakan jenis penelitian pre-eksperimental design, dikatakan pre-eksperimental design karena penelitian ini belum merupakan eksperimen sungguh-sungguh. Desain penelitian yang digunakan yaitu One-Group PretestPostest Design yaitu eksperimen yang dilaksanakan pada satu kelompok saja tanpa kelompok pembanding. Pada desain ini menggunakan pretest sebelum diberi perlakuan. Dengan demikian hasil perlakuan dapat diketahui lebih akurat, karena dapat membandingkan keadaan sebelum perlakuan (Hardianto \& Baharuddin, 2019) Untuk lebih jelasnya, peneliti menggambarkan desain dalam skema di bawah ini:

\section{$\mathrm{O}_{1} \mathrm{X} \mathrm{O}_{2}$}

\section{Gambar 1. Skema One Ggroup Pretest Posttest Design}

\author{
Keterangan Skema: \\ $\mathrm{O}_{1}=$ Sebelum perlakuan diberikan \\ $\mathrm{O}_{2}=$ Setelah perlakuan diberikan \\ $\mathrm{X}=$ Perlakuan yang diberikan
}

Karena pada penelitian ini hanya menggunakan satu kelas, itu artinya hanya ada kelompok eksperimen sebelum diberi perlakuan terlebih dahulu diberi pretest. Setelah pretes dilakukan barulah diberikan perlakuan dengan menggunakan bahan ajar cerita bergambar bermuatan religius. Postes dilakukan setelah perlakuan diberikan sehingga, peneliti dapat mengetahui secara lebih tepat prestasi belajar siswa sebelum dan sesudah perlakuan diberikan.

Subjek penelitian ini adalah siswa kelas 1 Sekolah Dasar Negeri Beji 03 sebanyak 30 siswa. Teknik pengumpulan data pada penelitian ini adalah teknik tes. 
Instrument yang digunakan untuk mengukur prestasi siswa adalah instrument tes. Tes yang digunakan berupa soal tes pilihan ganda berjumlah 20 soal. Sebelum tes digunakan untuk pretes dan postes, soal diujicobakan untuk mendapatkan kriteria soal yang baik. Dengan analisis inrumen tes meliputi validitas, reliabilitas, daya pembeda dan tingkat kesukaran soal. Analisis data menggunakan Uji gain ternormalisasi (N-Gain). Uji ini dilakukan untuk mengetahui peningkatan prestasi belajar setelah diberikan perlakuan. Peningkatan ini diambil dari nilai pretest dan postest siswa.

\section{HASIL DAN PEMBAHASAN}

Data yang diperoleh dari awal hingga akhir didapatkan dengan cara memberikan pretest kepada siswa sebelum mendapat perlakuan dengan menggunakan bahan ajar cerita bergambar bermuatan nilai religius dan pemberian postest kepada siswa setelah diberikan treatment. Bahan ajar cerita bergambar dengan bermuatan nilai religius ini memuat materi tentang mengenal bagian tubuh manusia, cara merawat bagian tubuh, mengenal panca indera dan merawat panca indera yang didalamnya terdapat nilai religius seperti kaidah surat At-Tin tentang kesempurnaan manusia dari makhluk hidup lainnya, doa sebelum dan sesudah makan, doa sebelum masuk dan keluar kamar mandi, doa sebelum tidur dan doa bangun tidur. Hasil penelitian yang didapatkan dari analisis data menggambarkan penelitian yang telah dilaksanakan. Data hasil penelitian yang didapatkan selanjutnya dianalisis untuk menginterprestasikan data yang telah tergabung sekaligus menjawab hipotesis penelitian. Berikut ini merupakan penjelasan dari hasil uji analisis instrument tes, nilai pretest dan postes siswa kelas 1 sekolah dasar.

Analisis instrument tes yaitu melalui uji coba soal tes prestasi belajar siswa yaitu uji validitas, reliabilitas, daya pembeda dan taraf kesukaran sehingga akan diperoleh soal yang layak untuk diolah sebagai hasil penelitian. Validitas tes pilihan ganda didapatkan dengan menggunakan rumus korelasi product moment. Hasil uji validitas diperoleh 20 soal valid dan 10 soal tidak valid dari 30 soal pilihan ganda yang di ujikan oleh peneliti. Dari 30 soal pilihan ganda diperoleh 20 soal valid yaitu nomor 2, 4, 7, 8, 10, 12, 13, 14, 17, 19, 20, 21, 22, 24, 25, 26, 27, 28, 29, 30. Dan 10 soal tidak valid yaitu nomor $1,3,5,6,9,11,15,16,18,23$. Berdasarkan hasil tersebut, maka peneliti menunggunakan 20 soal yang valid untuk diterapkan dalam penelitian pada soal pretes dan postes. 
Untuk menguji realibilitas instrumen penelitian ini, peneliti menggunakan rumus Sprearman Brown untuk tipe soal pilihan ganda. Hasil perhitungan reliabilitas butir soal bahwa diperoleh koefisiennreliabilitas 0,800, dan nilai koefisien reliabilitas 0,889 dengan kriteria sangat baik. Indeks kesukaran soal ini menunjukkan taraf kesukaran soal Kriteria yang digunakan adalah semakin kecil indeks yang diperoleh, semakin sulit/sukar soal tersebut. Dan semakin besar indeks yang diperoleh, semakin mudah soal tersebut. Hasil mengenai perhitungan tingkat kesukaran butir soal bahwa terdapat 6 soal dalam kategori mudah, 13 soal dalam kategori sedang, dan 1 soal dalam kategori sukar. Hasil dari perhitungan daya pembeda butir soal bahwa terdapat 6 soal dalam katerori daya pembeda jelek, 8 soal dalam kategori daya pembeda cukup, 5 soal dalam kategori daya pembeda baik, dan 1 soal dalam kategori daya pembeda sangat baik.

Keeffektivan diperoleh dari hasil penggunaan bahan ajar bermuatan nilai religus dalam upaya meningkatkan prestasi belajar siswa kelas 1 SD Negeri Beji 03 dapat diketahui melalui hasil pretes dan postes siswa. Data mengenai nilai pretest dan postes diperoleh siswa pada awal dan akhir pembelajaran. Siswa ditugaskan untuk mengerjakan soal pilihan ganda sebanyak 20 soal dan hasil dari nilai pretest dan postes materi bagian-bagian tubuh dan panca indera manusia dapat dilihat pada tabel berikut.

Tabel 1. Nilai Pretes dan Postes Siswa Kelas 1

\begin{tabular}{llcc}
\hline No & Indikator & Nilai Pretes & Nilai Postes \\
\hline 1. & Jumlah siswa & 30 & 30 \\
2. & KKM & 65 & 65 \\
3 & Nilai & 45 & 60 \\
& terendah & 80 & 90 \\
4 & Nilai tertinggi & 1890 & 2480 \\
5 & Jumlah nilai & 63 & 83 \\
6 & Nilai rata-rata & $(\mathrm{g})=\underline{2480-1890}=\underline{590}=0,53$ \\
& Uji Gain & $3000-1890$ & 1110 \\
& & & \\
\hline
\end{tabular}

Hasil dari keeffektivan penggunaan bahan ajar cerita bargambar dalam upaya meningkatkan prestasi belajar peserta didik klas 1 sekolah dasar negeri beji 03 tabel yang diketahui bahwa hasil pretes soal mengenal bagian-bagian tubuh,cara menjaga kesehatan tubuh, mengenal pancaindera serta merawat panca indera dari seluruh siswa adalah 1890 dan hasil postes dari seluruh siswa adalah 
2480. Hasil tersebut diolah menggunakan rumus $\mathrm{N}$-Gain dan mencapai nilai 0,53 dengan interpretasi "Sedang", dengan hasil ini maka terdapat peningkatan yang signifikan terhadap prestasi belajar siswa dengan menggunakan bahan ajar cerita bergambar bermuatan nilai religius. Bahan ajar memilik manfaat diantaranya adalah: 1) Pegangan untuk pendidik yang akan mengarahkan seluruh kegiatan proses pembelajaran, sekaligus menyampaikan subtansi yang diajarkan kepada siswa; 2) Pegangan siswa yang mengarahkan seluruh kegiatan dalam proses pembelajaran, sekaligus ialah subtansi kompetensi yang seyogyanya dipelajari atau dikuasi; 3) Mengukur pencapaian pembelajaran. Jadi, manfaat bahan ajar ini sangat berguna baik siswa mapun pendidik karena dengan adanya bahan ajar bisa mempermudah para pendidik untuk mentransfer ilmunya sehingga siswa mampu memahami materi yang diajarkan dengan mudah (Pratiwi et al., 2020).

Cerita bergambar merupakan suatu seni yang disusun sedemikian rupa yang membentuk suatu jalinan cerita dengan menggunakan gambar-gambar yang tidak bergerak. Penggunaan gambar dalam cerita tersebut diharapkan mampu menarik perhatian siswa untuk dapat membaca gambar yang disampaikan sehingga dapat memahami kata atau kalimat yang ditulis berdasarkan gambar (Bua et al., 2016). Gambar yang tercantum dalam teks sama-sama pentingnya di dalam buku cerita karena gambar sebagai perantara komunikasi dan menyampaikan pesan cerita kepada anak. Dengan kolaborasi antara tulisan dan gambar warna-warni maka akan menumbuhkan minat baca anak dan rasa ingin tahu tentang cerita dari buku tersebut. Dengan buku cerita yang disertai gambar warna-warni anak akan bersemangat membacanya.

Buku cerita bergambar adalah buku yang memadukan gambar menarik dengan kombinasi tulisan-tulisan yang isinya baik itu gambar maupun tulisannya sama-sama mempunyai fungsi yaitu untuk menyampaikan informasi Dalam pelaksanaan kegiatan pembelajaran, pendidik seharusnya tidak hanya menggunakan buku pokok dalam menyampaikan materi pembelajaran namun, pendidik dapat juga menggunakan buku pendamping dalam menunjang buku pokok sehingga pemahaman terkait dengan materi dapat membantu dan memperkuat pengetahuan peserta didik. Salah satu buku pendamping yang dapat digunakan pendidik adalah buku teks bergambar. Hal ini sesuai dengan pernyataan bahwa "peserta didik di sekolah dasar cenderung lebih suka, lebih senang membaca apabila, isi buku terdapat gambar yang menaik, dan lebih senang untuk membaca buku cerita bergambar" (Suryaningsih \& Fatmawati, 2017). Dari 
penjelasan di atas dapat disimpulkan bahwa, buku bergambar dapat membantu dalam memberi informasi tambahan kepada peserta didik atau buku bergambar dapat dimanfaatkan sebagai penopang dari buku pokok. Penelitian ini diperkuat penelitian sebelumnya dengan hasil terdapat pengaruh pemberian buku bergambar terhadap peningkatan pengetahuan tentang sayur (Romadhoni, 2018). Adapun penelitian lain dengan hasil ada peningkatan pengetahuan yang lebih tinggi dan bermakna secara statistik pada kelompok cerita bergambar, sehingga media cerita bergambar lebih efektif digunakan dalam meningkatkan pengetahuan sarapan sehat pada siswa sekolah dasar dibandingkan media leaflet (Gina, 2019).

\section{SIMPULAN}

Dari hasil penelitian dan pembahasan yang telah dipaparkan, dapat simpulan keeffektivan diperoleh dari hasil penggunaan bahan ajar cerita bergambar bermuatan nilai religus dalam upaya meningkatkan prestasi belajar siswa kelas 1 SD Negeri Beji 03 dapat diketahui melalui hasil pretes dan postes siswa. Hasil pretes soal mengenal bagian-bagian tubuh dan cara menjaga kesehatan tubuh dari seluruh siswa adalah 1890 dan hasil postes dari seluruh siswa adalah 2480. Hasil tersebut diolah menggunakan rumus $\mathrm{N}$-Gain dan mencapai nilai 0,53 dengan interpretasi "Sedang", dengan hasil ini maka terdapat peningkatan yang signifikan terhadap prestasi belajar siswa dengan menggunakan bahan ajar cerita bergambar bermuatan nilai religius.

\section{UCAPAN TERIMA KASIH}

Penulis ingin menyampaikan terimakasih kepada LPPM Unissula yang telah membantu biaya dalam pelaksanaan penelitian, Kepala Sekolah SD Beji 03 yang sudah mengijinkan untuk melaksanakan penelitian, dan kepada semua pihak yang telah membantu demi penyelesaian penelitian dan penulisan artikel ini.

\section{DAFTAR PUSTAKA}

Asfihani, K. (2019). Komik strip untuk media pembelajaran Matematika kelas V sekolah dasar. Jurnal Ilmiah Pendidikan Dasar, 6(2), 58-67. https://doi.org/10.30659/pendas.6.2.58-67

Aslach, Z. (2020). Pengaruh Kreativitas Siswa Dalam Model Pembelajaran Problem Based Learning Terhadap Prestasi Belajar Siswa Kelas Iv Sdn Kalisari 01. Jurnal Ilmiah Pendidikan Dasar, 7(1), 30. https://doi.org/10.30659/pendas.7.1.30-43

Bua, M., Santoso, A., \& Hasanah, M. (2016). Analisis minat membaca permulaan dengan cerita bergambar di kelas I sekolah dasar. Jurnal Pendidikan - Teori, 
Penelitian, Dan Pengembangan, 1(9), 1749-1752.

Effendy, Y., Bangsa, G., \& Yudani, H. D. (2013). Perancangan buku cerita bergambar Dang Gedunai untuk anak usia 4-6 tahun. Universitas Kristen Petra, 1(2), 56-58.

Fitriani, D., Nurwidodo, \& Wilujeng, E. C. (2019). Peningkatan hasil belajar siswa muatan IPS melalui model Student Facilitator and Explaining pada kelas IV-A SDN NGAGLIK 01. Jurnal Basicedu, 3(1), 208-213. https://doi.org/10.31004/basicedu.v3i1.108

Gina, H. (2019). Pengaruh pengembangan buku cerita bergambar terhadap peningkatan pengetahuan sarapan sehat pada siswa sekolah dasar. In Skripsi. Poltekkes Kemenkes Yogyakarta.

Hardianto, \& Baharuddin, M. R. (2019). Efektifitas penerapan model pembelajaran PAIKEM Gembrot terhadap peningkatan hasil belajar mahasiswa pada mata kuliah Pembelajaran Matematika Sekolah Dasar. Cokroaminoto Journal of Primary Education, 2(1), 27-33. https://doi.org/10.30605/cipe.212019.105

Lestari, I. (2018). Pengembangan bahan ajar Matematika dengan memanfaatkan Geogebra untuk meningkatkan pemahaman konsep. GAUSS: Jurnal Pendidikan Matematika, 1(1), 26-36.

Lestari, M. A., Eliyanti, M., \& Permana, A. (2017). Efektivitas penggunaan media buku cerita bergambar dalam penanaman nilai-nilai moral siswa SD kelas rendah. Pedagogi Jurnal Penelitian Pendidikan, 4(2), 134-144.

Pratiwi, S., Komala, E., \& Monariska, E. (2020). Pengembangan bahan ajar berbasis cerita bergambar Matematika. Jurnal Analisa, 6(2), 143-152. https://doi.org/10.15575/ja.v6i2.9033

Ratnasari, E. M., \& Zubaidah, E. (2019). Pengaruh penggunaan buku cerita bergambar terhadap kemampuan berbicara anak. Scholaria: Jurnal Pendidikan dan Kebudayaan, 9(3), 267-275. https://doi.org/10.24246/j.js.2019.v9.i3.p267-275

Romadhoni, I. (2018). Pengaruh pemberian media buku cerita bergambar terhadap peningkatan pengetahuan sayur dan buah pada siswa sekolah dasar. In Skripsi. Poltekkes Kemenkes Yogyakarta.

Setyarini, D. (2019). Metode pembelajaran Mind Map untuk meningkatkan prestasi belajar anak didik sekolah dasar. Jurnal Ilmiah Pendidikan Dasar, 6(1), 30-44. https://doi.org/10.30659/pendas.6.1.30-44

Suryaningsih, E., \& Fatmawati, L. (2017). Pengembangan buku cerita bergambar tentang mitigasi bencana erupsi gunung api untuk siswa SD/MI kelas IV di daerah rawan bencana. Profesi Pendidikan Dasar, 1(2), 113-124. https://doi.org/10.23917/ppd.v1i2.5310

Conflict of Interest Statement: The authors declare that the research was conducted in the absence of any commercial or financial relationships that could be constructed as a potential conflict of interest. 